\title{
Reniform Nematode, Rotylenchulus reniformis Linford \& Oliveira (Nematoda: Tylenchida: Tylenchoidea: Hoplolaimidae: Rotylenchulinae) ${ }^{1}$
}

Koon-Hui Wang ${ }^{2}$

\section{Introduction}

Reniform nematodes in the genus Rotylenchulus are semiendoparasitic (partially inside roots) species in which the females penetrate the root cortex, establish a permanent-feeding site in the stele region of the root and become sedentary or immobile. The anterior portion (head region) of the body remains embedded in the root whereas the posterior portion (tail region) protrudes from the root surface and swells during maturation. The term 'reniform' refers to the kidney-shaped body of the mature female.

There are ten species in the genus Rotylenchulus. Rotylenchulus reniformis is the most economically important species (Robinson 1997 ) and is called the reniform nematode.

\section{Distribution and Host Range}

Rotylenchulus reniformis is largely distributed in tropical, subtropical and in warm temperate zones in South America, North America, the Caribbean Basin, Africa, southern Europe, the Middle East, Asia,

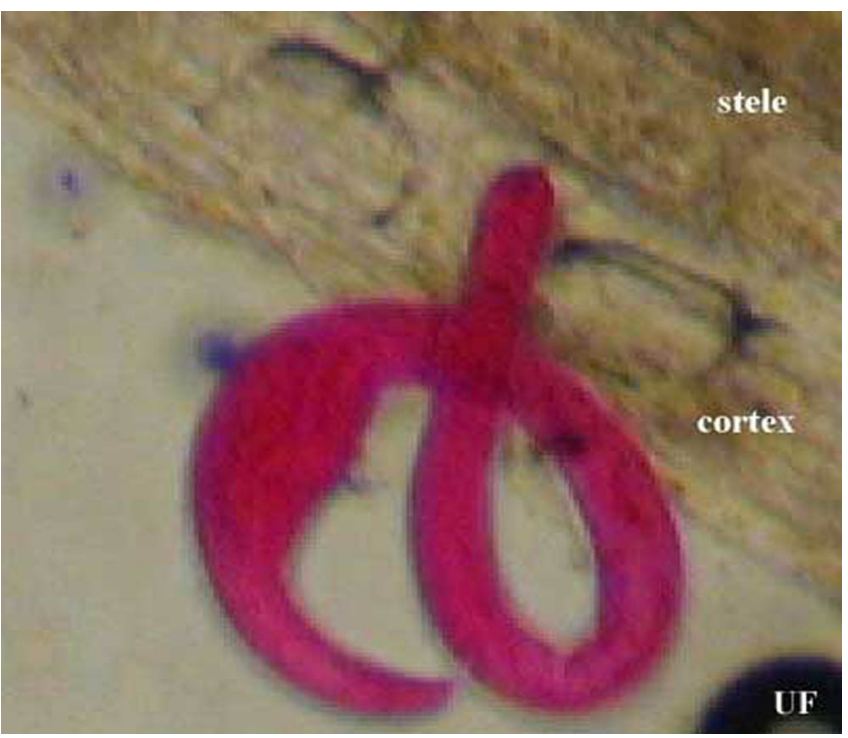

Figure 1. Young female of reniform nematode,

Rotylenchulus reniformis Linford \& Oliveira, with swollen body. The female penetrates the root of cowpea and the anterior portion (head region) of the body remains embedded in the root whereas the posterior portion (tail region) protrudes from the root surface. Credits: Koon-Hui Wang, University of Florida

1. This document is EENY-210, one of a series of Featured Creatures from the Entomology and Nematology Department, Florida Cooperative Extension Service, Institute of Food and Agricultural Sciences, University of Florida. Published: May 2001. This document is also available on Featured Creatures Website at http://creatures.ifas.ufl.edu. Please visit the EDIS Website at http://edis.ifas.ufl.edu and the Entomology and Nematology Department website at http://entnemdept.ifas.ufl.edu/.

2. Koon-Hui Wang, Department of Entomology, Institute of Food and Agricultural Sciences, University of Florida, Gainesville, FL.

The Institute of Food and Agricultural Sciences (IFAS) is an Equal Employment Opportunity - Affirmative Action Employer authorized to provide research, educational information and other services only to individuals and institutions that function without regard to race, creed, color, religion, age, disability, sex, sexual orientation, marital status, national origin, political opinions or affiliations. For information on obtaining other extension publications, contact your county Cooperative Extension Service office. Florida Cooperative Extension Service / Institute of Food and Agricultural Sciences / University of Florida / Larry R. Arrington, Interim Dean 
Australia, and the Pacific (Ayala and Ramirez 1964). It was first found on cowpea roots in Hawaii (Linford and Oliveira 1940), and first reported as a parasite of cotton in Georgia and of tomato in Florida. Today, it is found throughout the southern United States.

In Florida, reniform nematodes are especially common in southern counties, Dade and Monroe, where Rockdale soils in this area favor the reniform nematode population development. Reniform nematodes are also common in the northwestern counties of Florida (Panhandle region), from Jefferson to Santa Rosa, especially in the cotton production area with heavier soils such as sandy loam, sandy clay and clay loam (Kinloch and Sprenkel 1994).

At least 314 plant species are host to reniform nematodes. Among them, cotton, cowpea, soybean, pineapple, tea and various vegetables are the most common hosts. A list of hosts and nonhosts for reniform nematode was recently published by Robinson et al. (1997). Many weed and ornamental hosts to reniform nematode in Florida have been reported by Inserra et al. (1989, 1994a, b). In south Florida, sweet potato, papaya, and several edible aroids are excellent host to reniform nematodes, and the reniform nematode was associated with several kinds of tropical fruit trees (McSorley 1980; McSorley et al. 1982, 1983).

\section{Life Cycle}

Eggs hatch one to two weeks after being laid. The first-stage juvenile molts within the egg, producing the second-stage juvenile $(\mathrm{J} 2)$ that emerges from the egg. The infective stage is reached one to two weeks after hatch. Once root penetration occurs, one or two more weeks are required for females to reach maturity. The male, which remains outside of the root, can inseminate prior to the female gonad maturation, and sperms are stored in the spermatheca. Numbers of females and males in a population are usually equal. Some populations of reniform nematodes reproduce parthenogenetically, i.e., egg production without fertilization. Soon after female gonad maturation, the eggs are fertilized with sperm, and eggs are then deposited into a gelatinous matrix with about 60 to 200 eggs. The life cycle of this nematode is usually shorter than three weeks depends on soil temperature. However, it can survive at least two years in the absence of a host in dry soil through anhydrobiosis, a survival mechanism without water (Radewald and Takeshita 1964).

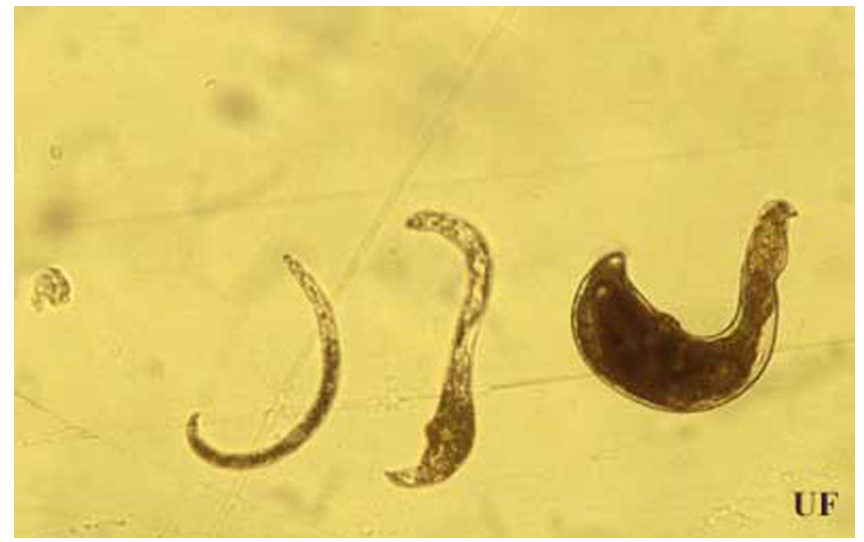

Figure 2. Life stages of reniform nematode, Rotylenchulus reniformis Linford \& Oliveira. Ranging from left to right is egg, juvenile, young female with swollen body, and mature female in kidney shape. Credits: Koon-Hui Wang, University of Florida

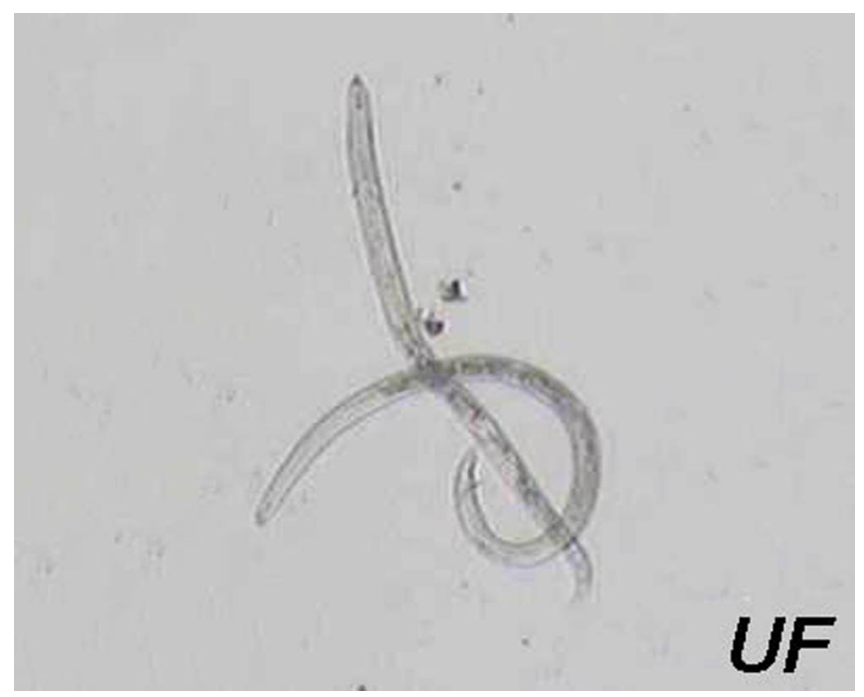

Figure 3. Male and young female of reniform nematode, Rotylenchulus reniformis Linford \& Oliveira, stages typically found in soil. Female has a strong stylet (needle-shaped mouthpart). Male (curved specimen) has a weak stylet and a spicule (at posterior) for insemination. Credits: Koon-Hui Wang, University of Florida

\section{Technical Description}

The average body length is about 0.34 to $0.42 \mathrm{~mm}$ for juveniles and males, and 0.38 to 0.52 for mature female nematodes. Rest in a $\mathrm{C}$ shape when killed by heat. The lip region of the young female is not offset, and the cephalic framework is 


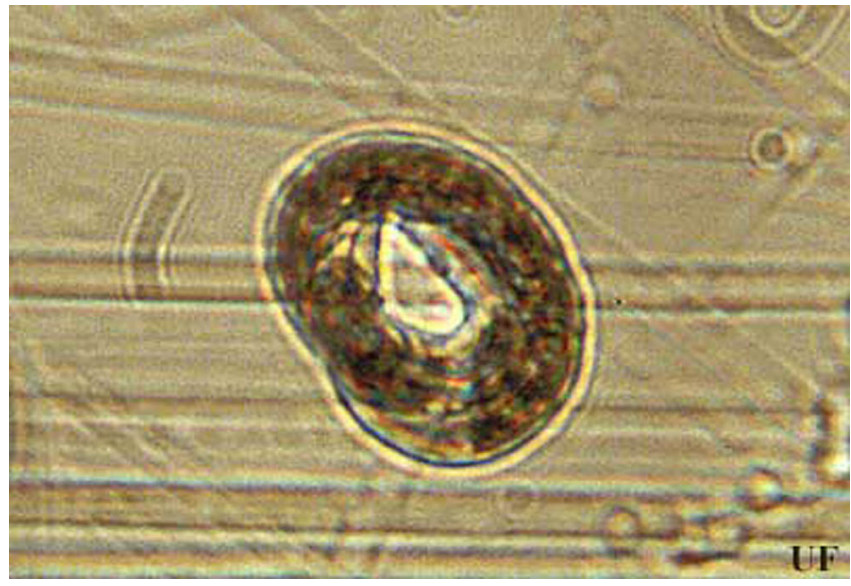

Figure 4. Reniform nematode, Rotylenchulus reniformis Linford \& Oliveira, tightly coiled to undergo anhydrobiosis under drought conditions. Credits: Koon-Hui Wang, University of Florida

conspicuous. The stylet, 16 to $21 \mu \mathrm{m}$ long, is of moderate strength with small rounded knob. The dorsal gland orifice is more than one-half the stylet length posterior to the base of stylet knobs. The basal glands overlap the intestine laterally, or less often ventrally. The vulva is post-median ( $\mathrm{V}>63 \%)$. The female reproductive system is amphidelphic with two flexures in immature females and highly convoluted in mature females. The female tail is usually more than twice the anal body diameter. The juvenile tail tapers to a narrow, rounded terminus with about 20 to 24 annules. Phasmids are porelike, about the body width or less behind anus. Males have weak stylets and stylet knobs, a reduced esophagus, and an indistinct median bulb and valve. Caudal alae are adanal. The lateral field of males, young females, and juveniles has four incisures which are not areolated (Mai and Mullin 1996).

\section{Economic Impact}

Only females infect plant roots. After infection, a feeding site composed of syncytial-cells is formed. A syncytial cell is a multinucleated cell resulting from cell wall dissolution of several surrounding cells.

Among the crops most severely affected by reniform nematode are upland cotton, pineapple and many vegetable crops including tomato, okra, squash, and lettuce. The university extension services in Mississppi and Alabama recommend nematicide treatment for cotton fields if population density exceeds two nematodes $/ \mathrm{cm}^{3}$ soil in the spring and 10 nematodes $/ \mathrm{cm}^{3}$ in fall or winter. Economic threshold for reniform nematode on pineapple is 310 nematodes $/ 250 \mathrm{~cm}^{3}$ soil (Sipes and Schmitt 2000). Reniform nematode population densities reduced snap bean yield by $10 \%$ in south Florida (McSorley et al. 1981). Besides the direct damage, reniform is also an important factor in the incidence of Fusarium and Verticillium wilts of cotton, causing the

Fusarium-wilt resistant varieties of cotton to become susceptible.

\section{Management}

No cotton and pineapple cultivars are resistant to reniform nematodes. Tolerant cotton breeding lines to reniform nematode had been developed. Soybean cultivars 'Peking', 'Dyer', 'Custer', and 'Pickett' are highly resistant to reniform nematode (Rebois et al. 1970). Certain tomato cultivars are resistant to this nematode (Balsubramanian and Ramakrishnan 1983).

Crop rotation with resistant or immune plant species is recommended. These include mustard (Brassica nigra), oats, rhodesgrass (Chloris gayana), onion, sugarcane, and sun hemp (Crotalaria juncea) (Robinson et al. 1997, Caswell et al. 1991). Pineapple is rotated with sugarcane or pagolagrass in Puerto Rico (Roman 1964). Sorghum, maize and reniform nematode resistant soybeans are recommended as rotation crops for cotton (Starr and Page 1990).

Currently, Hawaiian pineapple plantations manage plant-parasitic nematodes by fallowing after pineapple for six to 12 months, then fumigating before planting, and applying postplant non-fumigant nematicides (Apt and Caswell 1988). However, dry fallow may be ineffective as a means of control since this nematode can enter into anhydrobiosis in slowly drying soils and revives when environmental conditions are favorable (Apt 1976). Apt suggested that moist fallow would be more effective as a means of control. Fallow with weeds is also unfavorable because many weeds could be host to reniform nematode.

Areas free of reniform nematode impose regulation against this nematode. Chile and Switzerland are among the countries that have quarantine against reniform nematode. In the United States, Arizona, California and New Mexico restrict 
reniform nematode to protect their cotton industries. The ornamental industries of southern Florida and Hawaii are adversely affected by this regulation when the plant shipments are contaminated with reniform nematode. Therefore, expensive sanitation practices and the use of clean materials are required for ornamental plant nurseries.

For more information see:

Nematode Management Guide for Cotton (http://edis.ifas.ufl.edu/NG015).

Nematode Management Guide for Vegetables (http://edis.ifas.ufl.edu/TOPIC_GUIDE_ IG_Vegetables)

\section{Selected References}

Apt W Jr. 1976. Survival of reniform nematode in desiccated soils. Journal of Nematology 8: 278 (Abstract).

Apt W J, Caswell EP. 1988. Application of nematicides via drip irrigation. Annals of Applied Nematology 2: 1-10.

Ayala A, Ramirez CT. 1964. Host-range, distribution, and bibliography of the reniform nematode, Rotylenchulus reniformis, with special reference to Puerto Rico. Journal of Agriculture of University of Puerto Rico 48: 140-160.

Balasubramanian P, Ramakrishnan C. 1983. Resistance to the reniform nematode Rotylenchulus reniformis in tomato. Nematologia Mediterranea 11: 203-204.

Caswell EP, deFrank J, Apt WJ, Tang C-S. 1991. Influence of nonhost plants on population decline of Rotylenchulus reniformis. Journal of Nematology 23: 91-98.

Inserra RN, Dunn RA, McSorley R, Langdon KR, Richmer AY. 1989. Weed hosts of Rotylenchulus reniformis in ornamental nurseries of southern Florida. Nematology Circular No. 258. Florida Department of Agriculture and Consumer Services, Division of Plant Industry, Gainesville.
Inserra RN, Dunn RA, Volvas N. 1994a. Host response of ornamental palms to Rotylenchulus reniformis in Florida. Supplement to the Journal of Nematology 26: 737-743.

Inserra RN, Lehman PS, Overstreet C. 1994b Ornamental hosts of the reniform nematode, Rotylenchulus reniformis. Nematology Circular No. 209. Florida Department of Agriculture and Consumer Services, Division of Plant Industry, Gainesville.

Kinloch RA, Sprenkel RK. 1994. Plant-parasitic nematodes associated with cotton in Florida. Journal of Nematology 26: 749-752.

Linford MB, Oliveira JM. 1940. Rotylenchulus reniformis, nov. gen. n. sp., a nematode parasite of roots. Proceeding of the Helminthological Society of Washington 7: 35-42.

Mai WF, Mullin PG. 1996. Plant parasitic nematode. A Pictorial Key to Genera, $5^{\text {th }}$ Ed. Cornell University Press, Ithaca, New York.

McSorley R. 1980. Nematodes associated with sweetpotato and edible aroids in southern Florida. Proceedings of Florida State Horticultural Society 93: 283-285.

McSorley R, Campbell CW, Parrado JL. 1982. Nematodes associated with tropical and subtropical fruit trees in south Florida. Proceedings of Florida State Horticultural Society 95: 132-135.

McSorley R, Parrado JL, Stall WM. 1981. Aspects of nematode control on snapbean with emphasis on the relationship between nematode density and damage. Proceedings of Florida State Horticulture Society 94: 134-136.

McSorley R, Parrado JL, Conover RA. 1983. Population buildup and effects of the reniform nematode on papaya in southern Florida. Proceedings of Florida State Horticultural Society 96: 198- 200.

Radewald JD, Takeshita G. 1964. Desiccation studies on five species of plant-parasitic nematodes of Hawaii. Phytopathology 54: 903-904. 
Rebois RV, Epps JM, Hartwig EE. 1970.

Correlation of resistance in soybeans to Heterodera glycines and Rotylenchulus reniformis.

Phytopathology 60: 695-700.

Robinson AF, Inserra RN, Caswell-Chen EP, Vovlas N, Troccoli A. 1997. Rotylenchulus species: Identification, distribution, host ranges, and crop plant resistance. Nematropica 27: 127-180.

Roman J. 1964. Immunity of sugarcane to the reniform nematode. Journal of Agriculture, University of Pueto Rico 48: 162-163.

Sipes BS, Schmitt DP. 2000. Rotylenchulus reniformis damage thresholds on pineapple. Acta Horticulturae 529: 239-245.

Starr JL, Page SL. 1990. Nematode parasites of cotton and other tropical fiber crops. pp. 539-556. In: Plant parasitic nematodes in subtropical and tropical agriculture. Luc M, Sikora RA, Bridge J (eds). CAB International, Oxon, UK. 